\title{
Review Article \\ MAP-BASED CLONING IN VEGETABLE CROPS: A REVIEW
}

\author{
KUMAR MANISH* AND KAUR MANPREET \\ Division of Vegetable Sciences, ICAR-Indian Agricultural Research Institute, New Delhi, 110012, India \\ *Corresponding Author: Email - imanishkumar91@gmail.com
}

Received: March 16, 2018; Revised: April 23, 2018; Accepted: April 24, 2018; Published: April 30, 2018

\begin{abstract}
In the fast-changing world, the trend of vegetable consumption is increasing and molecular science has emerged unequivocally as the leading discipline for its genetic improvement. Cloning of genes governing important traits is one of the main objectives of molecular genetics. The map-based cloning approach has been applied in plant genetics to identify genes having a major effect on the phenotypic variations. Characterizing the causative allelic variation establishes the in vivo function of genes. The basic idea behind map-based cloning is to clone the gene based on knowing its chromosomal location. Map-based cloning or positional cloning refers to the process to recognize the underlying cause of variation in a mutant phenotype without prior assumptions or knowledge of specific genes. For this approach to be successful, a large number of polymorphic markers are required to delimit the gene within a sufficiently small genetic interval of less than $1 \mathrm{cM}$. Statistical association analyses between molecular polymorphisms of the candidate genes and variation in the trait of interest have also been carried out in a few studies. To validate the gene, physiological analyses, genetic transformation and/or sexual complementation experiments are practiced. A brief summary of fine mapped/cloned genes in vegetable crops is discussed here. The goal of this paper is to present an overview of map-based cloning analyses in plant genetics with special reference to vegetable crops.
\end{abstract}

Key words- Map-based cloning, Fine mapping, Gene, Molecular marker, Vegetable

Citation: Kumar Manish and Kaur Manpreet (2018) Map-Based Cloning in Vegetable Crops: A Review. International Journal of Genetics, ISSN: 0975- 2862 \& E-ISSN: 0975-9158, Volume 10, Issue 4, pp.-394-400. DOl: http://dx.doi.org/10.9735/0975-2862.10.4.394-400

Copyright: Copyright@2018 Kumar Manish and Kaur Manpreet. This is an open-access article distributed under the terms of the Creative Commons Attribution License, which permits unrestricted use, distribution and reproduction in any medium, provided the original author and source are credited.

\section{Introduction}

World Health Organization (WHO) recommends a minimum intake of 400 grams per capita of fruits and vegetables consumptions per day to ensure nutritional security over the world [1]. Owing the limited availability coupled with high price make it difficult to meet the WHO recommendation in developing countries like India. Nutritional security is projected to continuance improvement as development of improved vegetable varieties/hybrids/ technologies through systematic research coupled with their adoption by the farmers and developmental policies of the government, ultimately leading to increased fruit and vegetable consumption. Urbanization, Health consciousness, shifting of farmers to high value vegetables due to higher income, favorable elasticity of demand and annual growth rate for domestic demand for fruits \& vegetables are important ingredients for fuelling vegetable growth in the country [2]. The country has witnessed tremendous progress in horticulture crop production, surpassing the food grain production at a record 300.6 MT [3]. Amidst, factors like alarming increase in population, limited possibility of expanding arable land, water scarcity, erosion of fertile topsoil, lack of improvement of local plant types and erosion of genetic diversity posing threat to continue this trend. Therefore, plant breeders and geneticists are under constant pressure to sustain and expand vegetable production by using innovative molecular breeding strategies rather relying on ready availability of genetic variation, either spontaneous or induced and other traditional methods of crop improvement.

Map-based cloning is a unique approach to recognize the genetic basis of a mutant phenotype with the help of linkage to markers whose physical location in the genome is known. The identification of the genetic mutation causative for an observed trait is the final step in the forward genetic process. While optional, this is an important step for several reasons. Characterizing the causative allelic variation establishes the in vivo function of genes [4]. The basic idea behind this method is to clone the gene based on knowing its chromosomal location. In a map-based cloning, one starts with a genetic map of the organism's genome, finds a cloned marker that is close to the gene of interest, and then searches library DNA for clones that are near the previously cloned marker. By wandering around in the right neighborhood, one eventually clones the gene of interest. Map-based cloning is tedious, hampering the quick identification of candidate genes [5]. For this approach to be successful, a large number of polymorphic markers are required to delimit the gene within a sufficiently small genetic interval of less than $1 \mathrm{cM}[6]$. Whole genome sequencing of model plant, Arabidopsis sp. for genetic studies has further accelerated the crop improvement projects [7]. Molecular marker development has also paved the way by invention of environmentally insensitive DNA-based marker systems such as restriction fragment length polymorphism (RFLP) analysis [8] and PCR-based markers such as random amplified polymorphic DNA (RAPD) [9], simple sequence repeats (SSR) [10] and amplified fragment length polymorphisms (AFLPs) [11] [Table-1]. Therefore, molecular marker availability is no longer a limitation for map-based cloning of any organism. Moreover, complete sequencing of Solanaceous (Tomato and Chili) and Cucurbitaceous crops (melons, cucumber and bottle gourd) enable vegetable breeder to assign markers a physical position on the map.

Map-Based Cloning Strategies

Map-based cloning approach for identification of candidate gene utilizes the fact that, as distances between the gene of interest and the analyzed markers decrease, so does the frequency of recombination [5]. The first step toward successful map-based cloning is the mapping of the target gene in a segregating population. 
Once markers are found linked to the target gene, this region can be saturated with DNA markers, using a variety of methods, to obtain more closely linked markers. The next step is to establish the relationship between genetic and physical distance by physical mapping of the most closely linked markers. This step is crucial to the success of a map-based cloning effort because the correspondence between genetic and physical distances can vary over 100 -fold in different regions of a genome [12]. The third step is to use the most closely linked markers as starting points for chromosome walking or jumping toward the target gene. Chromosome walking is continued until a genomic clone is isolated that can be determined genetically to contain the target gene. Finally, once a candidate clone is isolated, target gene identity must be determined to prove that the gene has been isolated (e.g., phenotypic complementation in transgenic plants). This general strategy has been successfully employed in mammalian systems, most notably for the cystic fibrosis gene [13]. Recently, several strategies have been developed that allow one to screen a large number of random, unmapped molecular markers in a relatively short time and to select just those few markers that reside in the vicinity of the target gene. These methods rely on two principles: (1) the development of high-volume marker technology, which allows hundreds or even thousands of potentially polymorphic DNA segments to be generated and visualized rapidly from single preparations of DNA; and (2) use of genetic stocks to identify, among these thousands of DNA fragments, those few that are derived from a region adjacent to the targeted gene. High-volume marker technologies that have demonstrable efficacy are RAPDs, AFLPs, RFLP subtraction [14], SSR, and single nucleotide polymorphism (SNP) [15]. An interesting and, for plants, relatively new approach to identifying linked markers is linkage disequilibrium mapping in natural populations. Map-based cloning in plants has only recently been demonstrated in the model plant Arabidopsis thaliana by isolation of the $A B / 3$ gene [16] and the omega-3 fatty acid desaturase gene [17]. In general, Quantitative Trait Loci (QTLs) identified through either linkage mapping or association mapping based approaches has low resolution and has been located at 10-20 cM intervals. Such intervals may span several hundreds of genes and identifying the right candidate gene(s) with causal effect on the given trait is like finding a genic needle in the genomic haystack. Therefore, to identify the causal gene(s), positional cloning of QTLs has been undertaken in several crop species. One way to identify the gene of interest is to order the appropriate targetinginduced local lesions in genomes (TILLING) lines and/or lines in which the candidate genes are tagged by a T-DNA or transposon. Further phenotyping and allelism study of these lines identifies the gene of interest. Validation of candidate genes can be performed by genetic transformation of the wild-type version of the gene of interest to test the expression of mutant under study.

\section{Map-Based Cloning in Vegetables \\ Tomato}

Tomato was the first plant species in which a disease resistance gene, pto, conferring resistance to bacterial speck caused by Pseudomonas syringae pv. tomato (Pst), was cloned using map-based cloning approach [18]. Subsequently, a similar map-based cloning strategy was employed and several other tomato genes were cloned, including Prf, which is required for Pto activity and tomato resistance to $P$ st and which also confers tomato susceptibility to organophosphate insecticide, Fenthion [19] and [20]. Apart from this, Sw- 5 conferring resistance to tospovirus [21], sp (self pruning) [22], members of $s p$ gene family [23], $j$ and $j-2$ controlling jointless pedicel [24] were also reported in tomato crop. As indicated earlier, jointless pedicel is an essential character and widely used in the processing tomato industry as it aids mechanical harvesting and prevents physical wounding during transportation. Jointless pedicel is also becoming highly desirable in fresh market tomato cultivars. In addition, during the past decade, several other major genes in tomato have been fine-mapped and/or cloned via map-based cloning approach [Table-2]. During the past decade, efforts have been made to clone QTLs and determine whether QTLs have the same molecular basis as Mendelian genes [25]. Much of such efforts have been made in tomato as a model species [26]. For example, the first map-based cloning of a QTL in plants was carried out by [27] in tomato for fruit size (fw2.2). Because of its large, consistently detectable effects significant efforts were made to clone and characterize this QTL. In a complementation test, when a cosmid obtained from fw2.2 region of a small-fruited wild species (L. pennellii) was transformed into large fruited cultivars, it resulted in reduction in fruit size. By applying a map-based cloning approach, fw2.2 was cloned, sequenced, and characterized [28] and [29]. Furthermore, it was determined that this gene was expressed early in floral development and controls carpel cell number. Following this remarkable advancement, similar strategy has been used in tomato to fine map and/or clones a few other QTLs affecting traits such as soluble solids content, fruit shape, and exerted stigma. However, it is expected that with advancements in marker technology and QTL identification, more and more QTLs will be fine-mapped and cloned using positional cloning strategy.

\section{Capsicum}

Locus corresponding to Bs2 gene confers resistance to strains of Xanthomonas campestris pv. vesicatoria was isolated and found to encode motifs characteristic of the nucleotide binding site-leucine-rich repeat class of resistance genes controlled hypersensitive response in susceptible pepper and tomato lines and in a non host species, Nicotiana benthamiana when transiently expressed [30]. Fine mapping of Restorer of fertility $(R f)$, pepper trichome locus 1 controlling trichome formation and temperature-sensitive gene from Capsicum chinense (sy-2) [31] and [32] is also provide useful information for map-based cloning of these important traits and may enable a better understanding of the molecular mechanisms underlying these genes. Other genes that account for well-known phenotypes in pepper that have been isolated include polygalauctouronase [33], capsanthin capsorubin synthase [34], phytoene synthase [35] and [36], Pun1 [37] and pvr 1 [38] and [39].

\section{Cole Crops}

Functional role of Or gene is associated with a cellular process that triggers the differentiation of proplastids or other noncolored plastids into chromoplasts for carotenoid accumulation and it can be used as a novel genetic tool to induce carotenoid accumulation in a major staple food crop. Using positional cloning, Orange (Or) gene in cauliflower (Brassica oleracea var. botrytis) was isolated and verified by functional complementation in wild-type cauliflower [40]. Yellow wilt poses serious threat to summer cultivation of cabbage crop worldwide, and therefore breeding programs assisting in development of yellow wilt resistant varieties are utmost important. Shimizu, et al., (2014) fine mapped the FocBo1 locus controlling type $A$ resistance in $\mathrm{F} 2$ plants obtained from double haploid lines from resistant cabbage (AnjuP01) and susceptible broccoli (GCP04) [41]. The FocBo1 region was delimited to a $360 \mathrm{~kb}$ region where a NBS-LRR type gene, which is a candidate of FocBo1 was found. The association analysis using the DNA markers detecting polymorphisms between resistant and susceptible alleles of the locus in F1 cultivars and F2 populations suggested that the locus contains the FocBo1 gene [42]. A dominant genic male sterile (DGMS) gene Ms-cd1 was mapped to a 39.4- kb DNA fragment between two InDel markers, InDel14 and InDel24 on chromosome C09 of cabbage (Brassica oleracea). ORF designated Bol357N3 was identified as the candidate of the Ms-cd1 gene will be useful to reveal the molecular mechanism of the DGMS and develop more practical DGMS lines with stable male sterility for hybrid seed production in cabbage [43]. Mapbased cloning has been successfully employed to isolate fertility restorer genes of Rfk1 and Rfo from radish [44] and [45]. Recently, the fertility resteror gene (Rf) for cytoplasmic male sterility in radish has successively been cloned by the mapbased cloning strategy. A combination positional cloning and microsynteny analysis between Arabidopsis and radish and tightly linked AFLP marker to fertility restorer gene (Rfo) orthologous to Arabidopsis chromosome 1 was reported by [46] and [47].

Sugarbeet: Hs1 (pro-1) gene confers resistance to beet cyst nematode (Heterodera schachtii Schmidt), was cloned with the use of genome-specific satellite markers and chromosomal break-point analysis. The native Hs1(pro-1) gene, expressed in roots, encodes a 282-amino acid protein with imperfect leucine-rich repeats and a putative membrane-spanning segment, features similar to those of disease resistance genes previously cloned from higher plants [48] 
Table-1 Molecular Marker System

\begin{tabular}{|c|c|c|c|}
\hline \multirow{2}{*}{\multicolumn{4}{|c|}{$\begin{array}{l}\text { Marker system } \quad \text { Advantages } \\
\text { First-Generation Markers based on Restriction Fragment Detection }\end{array}$}} \\
\hline & & & \\
\hline $\begin{array}{l}\text { Restriction Fragment Length } \\
\text { Polymorphism (RFLP) }\end{array}$ & Co-dominant and highly reproducible & $\begin{array}{l}\text { High on time/labour. Large amounts of high quality DNA } \\
\text { required }\end{array}$ & [8] \\
\hline \multicolumn{4}{|c|}{ Second-generation markers based on PCR } \\
\hline $\begin{array}{l}\text { Cleavage amplification } \\
\text { polymorphism (CAP) }\end{array}$ & Insensitive to DNA methylation, no requirement for radioactivity & Produces informative PCR products & {$[57]$} \\
\hline $\begin{array}{l}\text { Random amplified polymorphic } \\
\text { DNA (RAPD) }\end{array}$ & Low on time/labour, medium multiplex ratio & Dominant, low reproducibility & [9] \\
\hline $\begin{array}{l}\text { Amplified fragment length } \\
\text { polymorphism (AFLP) }\end{array}$ & High reproducibility; high muliplex ratio & Dominant; moderate time/labour & [11] \\
\hline $\begin{array}{l}\text { Sequence-specific amplification } \\
\text { polymorphism (S-SAP) }\end{array}$ & Applicable for targeting any gene, transposon or sequence of interest & $\begin{array}{l}\text { Sequence must be known to enable design of element specific } \\
\text { PCR primers }\end{array}$ & [57] \\
\hline $\begin{array}{l}\text { Simple sequence repeat } \\
\text { (microsatellite) (SSR) }\end{array}$ & Co-dominant, highly reproducible, low on time and labour & High cost of development, low multiplex ratio & {$[57]$} \\
\hline $\begin{array}{l}\text { Inter-simple sequence repeat } \\
\text { (ISSR) }\end{array}$ & $\begin{array}{l}\text { Technically simple, no prior genomic information needed to reveal both inter } \\
\text { and intraspecific variation }\end{array}$ & Dominant markers, band staining can be weak & [57] \\
\hline $\begin{array}{l}\text { Variable number tandem repeat } \\
\text { (minisatellite) (VNTR) }\end{array}$ & Numerous multiallelic loci & Low-resolution fingerprints in plants & [57] \\
\hline Sequence tagged sites (STS) & Co-dominant; useful for mapping & Reproducibility; based on some degree of sequence knowledge & [57] \\
\hline $\begin{array}{l}\text { Sequence characterized } \\
\text { amplification region (SCAR) }\end{array}$ & May be dominant or co-dominant; better reproducibility than RAPDs & More difficult to reproduce than RAPDs & [57] \\
\hline $\begin{array}{l}\text { Sequence amplification of } \\
\text { microsatellite polymorphic loci } \\
\text { (SAMPL) }\end{array}$ & High multiplexing, co-dominant markers; extensive polymorphism & Some blurred banding; stutter bands & [57] \\
\hline \multicolumn{4}{|c|}{ Third-generation markers based on DNA sequencing } \\
\hline $\begin{array}{l}\text { Single nucleotide polymorphism } \\
\text { (SNP) }\end{array}$ & $\begin{array}{l}\text { Common; evenly distributed; detection easily automated; high throughput; low } \\
\text { assay cost; useful for association studies; potentially high multiplex ratio }\end{array}$ & Usually only two alleles present & [57] \\
\hline \multicolumn{4}{|c|}{ Genome scanning for expressed genes } \\
\hline Expressed sequence tag (EST) & $\begin{array}{l}\text { Easy to collect and sequence; reveals novel transcripts; good representation of } \\
\text { transcripts }\end{array}$ & Error-prone; isolation of mRNA may be difficult & [57] \\
\hline $\begin{array}{l}\text { Sequence-related amplified } \\
\text { polymorphism (SRAP) }\end{array}$ & $\begin{array}{l}\text { Simplicity; high throughput; numerous co-dominant markers; high } \\
\text { reproducibility; targets coding sequences; detects multiple loci without previous } \\
\text { knowledge of sequence information; PCR products directly sequenced }\end{array}$ & $\begin{array}{l}\text { Detects co-dominant and dominant markers, which can lead to } \\
\text { complexity; null alleles detected directly }\end{array}$ & [57] \\
\hline $\begin{array}{l}\text { Target recognition amplification } \\
\text { protocol (TRAP) }\end{array}$ & $\begin{array}{l}\text { Simple to use; highly informative; produces numerous markers by using } \\
\text { existing public EST databases; uses markers targeted to a specific gene }\end{array}$ & $\begin{array}{l}\text { Requires CDNA or EST sequence information for primer } \\
\text { development }\end{array}$ & [57] \\
\hline \multicolumn{4}{|l|}{ Markers using array technology } \\
\hline $\begin{array}{l}\text { Microarrays (arrangements of } \\
\text { small spots of DNA fixed to glass } \\
\text { slides) }\end{array}$ & $\begin{array}{l}\text { Whole-genome scanning; high-throughput technology; genotype-phenotype } \\
\text { relationship; expression analysis of large numbers of genes }\end{array}$ & Expensive; needs gene sequence data; technically demanding & [57] \\
\hline Diversity array technology (DArT) & $\begin{array}{l}\text { No sequence data required; high throughput; detects single base changes and } \\
\text { indels; rapid germplasm characterization }\end{array}$ & Dominant markers; technically demanding & [57] \\
\hline \multicolumn{4}{|l|}{ Other marker systems } \\
\hline $\begin{array}{l}\text { Single-strand conformational } \\
\text { polymorphism (SSCP) }\end{array}$ & Detects DNA polymorphisms and mutations at multiple sites in DNA fragments & Temperature-dependent; sensitivity affected by $\mathrm{pH}$ & [57] \\
\hline $\begin{array}{l}\text { Denaturing gradient gel } \\
\text { electrophoresis (DGGE) }\end{array}$ & $\begin{array}{l}\text { Separates individual sequences from a complex mixture of microbes based on } \\
\text { sequence differences }\end{array}$ & $\begin{array}{l}\text { PCR fragment size limited to about } 500 \mathrm{bp} \text {; difficult to resolve } \\
\text { fragments that differ by only one or two bases }\end{array}$ & [57] \\
\hline $\begin{array}{l}\text { Temperature gradient gel } \\
\text { electrophoresis (TGGE) }\end{array}$ & Almost identical to DGGE; more reliable; uses temperature gradient & Technically demanding; little used in plants & [57] \\
\hline Methylation-sensitive PCR & \multicolumn{2}{|l|}{ Detects sites of methylated DNA } & [57] \\
\hline
\end{tabular}

\section{Cucurbits}

\section{Cucumber}

Using map-based cloning with an F2 segregating population of 721 individuals generated from NC073 and WT line SA419-2 of cucumber, ts gene, involved in the initiation of multicellular tender spine in cucumber was identified. It was located between two markers Indel6239679 and indel6349344, $109.7 \mathrm{~kb}$ physical distance on chromosome 1 containing fifteen putative genes. The gene encodes a C-type lectin receptor-like tyrosine-protein kinase which would play an important role in the formation of cucumber fruit. This is firstly reported of a receptor kinase gene regulating the development of multicellular spines/trichomes in plants. The ts allele could accelerate the molecular breeding of cucumber soft spines [49]. The mapping population consisting of $9497 \mathrm{~F} 2$ plants delimited the controlling white color in immature cucumber fruit to an 8.2-kb physical interval that defines a sole candidate gene, APRR2. Single-base insertion in the white color gene $w$, which leads to a premature stop codon is hypothesized to have disabled the function of this gene in chlorophyll accumulation and chloroplast development [50].

\section{Melons}

The first gene in cucurbits cloned by map-based cloning approach was disease resistance genes in melon, Fom-2 [51], followed by Vat [52], and nsv [53, 54]. The cloned Fom-2 shared a high similarity to the previously characterized NBS-LRR class of resistance gene 12 in tomato [55] and [56]. Sequence comparison indicated that the domain of the Fom-2 LRR was identical in the two resistant lines (MR-1 and PI161375) tested except for three nucleotides which resulted in the substitution of two residues $V$ and $K$ in $M R-1$ with $M$ and $E$ in $P I 161375$, respectively. LRR domain sequences from the susceptible genotype (Vedrantais, AY and Durango) were identical but 25 amino acids out of 541 were different from those of the resistant sequences. Another resistance gene, Vat has also been cloned. Vat confers resistance to colonization by the melon/ cotton aphid and resistance to transmission of unrelated Cucumber mosaic virus (CMV) and potyviruses. The cloned Vat belongs to the coiled-coil (CC) NBS/LRR class of plant disease resistance genes. The gene is $6 \mathrm{~kb}$ in size with three introns and encodes a protein of 1473 amino acid. The Vat locus contains resistance gene homologs including other Vat-like sequences that do not confer any known resistance. Function of this gene was confirmed by complementation of susceptible melon varieties. Using genetic and physical mapping delineated the location of nsv gene that confers resistance to Melon necrotic spot virus. From a 15-BAC clone contig spanning 1.2cM, one BAC clone (1-21-10) was identified which contained the gene with co-segregated marker 52K20sp6. The delineation was carried out using $408 \mathrm{~F} 2$ plants and 2727 backcross progeny. The single BAC clone now can be sequenced to identify the candidate nsv gene. Cloned disease resistance genes can be transferred to other susceptible melon lines to enhance their resistance to damaging pathogens either through transformation or traditional breeding aided by MAS via markers developed from these genes. They can also be introduced into other cucurbits to determine if heterologous expression of these genes affects host resistance. The sequence of cloned genes could allow for the development of a unique marker that could aid the selection of functional resistance gene during plant improvement. 
Table-2 Fine-Mapped and/or Cloned Genes and QTLs in Vegetable Crops

\begin{tabular}{|c|c|c|c|c|c|c|}
\hline Traits & Gene/ QTL & Chr.No. & Source Species & $\begin{array}{l}\text { Mapping } \\
\text { Population }\end{array}$ & Nature/Activity/ Function & References \\
\hline \multicolumn{7}{|c|}{ Pest Resistance } \\
\hline Aphid Resistance & Meu-1 & 6 & L. peruvianum & $\mathrm{NIL} \mathrm{F}_{2}$ & NBS-LRR & {$[58],[59],[60]$} \\
\hline Bacterial Speck Resistance & Pto & 5 & L. pimpinellifolium & $\mathrm{NIL} \mathrm{F}_{2}$ & $\begin{array}{l}\text { Protein Kinase } \\
\text { Serine, Threonine }\end{array}$ & $\begin{array}{l}{[18],[61] \text { and }} \\
{[62]}\end{array}$ \\
\hline Fusarium Wilt Resistance & 12 & 11 & L. esculentum & $\mathrm{NIL} \mathrm{F}_{2}$ & Leucine Zipper and LRR-NBS & {$[56]$} \\
\hline Leaf Mould Resistance & $\begin{array}{l}\text { Cf-2, Cf-4, } \\
\text { Cf-5, Cf-9 }\end{array}$ & 1,6 & L. peruvianum & $\mathrm{NIL} \mathrm{F}_{2}$ & LRR & [63] \\
\hline $\begin{array}{l}\text { Nematode (Rootknot) } \\
\text { Resistance }\end{array}$ & $\begin{array}{l}M i-1.1 \\
M i-1.2\end{array}$ & 6 & L. peruvianum & $\mathrm{NIL} \mathrm{F}_{2}$ & NBS-LRR & $\begin{array}{l}{[58],[59] \text { and }} \\
{[60]}\end{array}$ \\
\hline $\begin{array}{l}\text { Tomato Spotted } \\
\text { Wilt Virus }\end{array}$ & $S w-5$ & 9 & L. peruvianum & NIL $F_{2}$ & $\begin{array}{l}\text { NBS-LRR } \\
\text { Resistance gene }\end{array}$ & {$[21]$} \\
\hline $\begin{array}{l}\text { Xanthomonas compestris } \\
\text { pv. vesicatoria }\end{array}$ & Bs 2 & & Pepper, & $\mathrm{F}_{2}$ & NBS-LRR & {$[30]$} \\
\hline $\begin{array}{l}\text { Fusarium Yellows } \\
\text { Resistance }\end{array}$ & FocBo1 & 7 & Brassica oleracea & $\mathrm{F}_{2}$ & NBS-LRR & [41] and [42] \\
\hline Cyst Nematode Resistance & Hs1-Pro & 1 & Sugarbeet & $\mathrm{F}_{2}$ & $\begin{array}{l}\text { NBS-LRR } \\
\text { Resistance gene }\end{array}$ & {$[48]$} \\
\hline $\begin{array}{l}\text { Fusarium oxysporum f.sp. } \\
\text { melonis }\end{array}$ & Fom-2 & & Melon & $\mathrm{RIL}, \mathrm{BC}_{1}$ & NBS-LRR & {$[51]$} \\
\hline Aphis gossypii & Vat & 5 & Melon & $\mathrm{RIL}, \mathrm{BC}_{1}$ & NBS-LRR & [52] \\
\hline Melon necrotic spot virus & Nsv & 11 & Cucumis melo & $\mathrm{F}_{2, \mathrm{BC} 1}$ & & [53] and [54] \\
\hline Phytophtohora infestans & $R 8$ & 09 & S. demissum & $\mathrm{F}_{1}$ & NBS-LRR & [64] \\
\hline Plasmodiophora brassicae & Rcr2 & 03 & Brassica napus & $\mathrm{F}_{1}$ & TIR-NBS-LRR & [65] \\
\hline $\begin{array}{l}\text { Pepper mottle virus } \\
\text { (Pepmov) }\end{array}$ & Pvr7 & 10 & C. annuum & $\mathrm{F}_{2}$ & NB-LRR & {$[66]$} \\
\hline Powdery Mildew & PMR1 & 04 & Capsicum annuum & $F_{2: 3}, F_{2}$ & NBS-LRR & {$[67]$} \\
\hline Tomato Spotted Wilt Virus & Tsw & 10 & Capsicum annuum & $\mathrm{F}_{2}$ & NBS-LRR & [68] \\
\hline Bean Rust & Ur-3 & 11 & Phaseolus vulgaris & $\mathrm{F}_{2}$ & NB-ARC LRR & [69] \\
\hline $\begin{array}{l}\text { Angular Leaf Spot } \\
\text { Resistance }\end{array}$ & ALS4.1GS & 04 & Phaseolus vulgaris & $\mathrm{F}_{3}$ & $\begin{array}{l}\text { Serine/Threonine } \\
\text { Protein Kinases }\end{array}$ & [70] \\
\hline \multicolumn{7}{|c|}{ Morphological Traits } \\
\hline Flower, Exerted Stigma & $\operatorname{se2.1(Q)}$ & 2 & L. pennellii & $\mathrm{F}_{3}$ & Aspects of Floral Morphology & [71] \\
\hline Fruit Color (B-Carotene) & $B$ & 6 & L. pennellii & $\mathrm{NIL} \mathrm{F}_{2}$ & Lycopene $\beta$-cyclase & [72] and [73] \\
\hline Fruit Color (Crimson) & $\mathrm{og}^{c}, \mathrm{cr}$ & 6 & L. esculentum & $\mathrm{NIL} \mathrm{F}_{2}$ & Lycopene cyclase null Allele & [72] and [73] \\
\hline Fruit Color (Old Gold) & $\mathrm{Og}$ & 6 & L. esculentum & $\mathrm{NIL} \mathrm{F}_{2}$ & Lycopene Cyclase null allele & [73] \\
\hline Fruit Color (Tangerine) & CRISTO & 10 & L. esculentum & $\mathrm{NIL} \mathrm{F}_{2}$ & Carotenoid Isomerase & [74] \\
\hline Fruit Ripening (Never Ripe) & $\mathrm{Nr}$ & 9 & L. esculentum & NIL $F_{2}$ & Blocks Ethylene Perception & [75] \\
\hline $\begin{array}{l}\text { Fruit Ripening (Nonripen } \\
\text { Ing)- }\end{array}$ & Nor & 10 & L. esculentum & $\mathrm{NIL} \mathrm{F}_{2}$ & $\begin{array}{l}\text { MADS-box } \\
\text { Transcription factor }\end{array}$ & [76] \\
\hline $\begin{array}{l}\text { Fruit Ripening (Ripening } \\
\text { Inhibitor) }\end{array}$ & Rin & 5 & $\begin{array}{l}\text { L. esculentum } \\
\text { L. cheesmanii } \\
\text { L. pennellii }\end{array}$ & $\mathrm{NIL} \mathrm{F}_{2}$ & $\begin{array}{l}\text { MADS-box } \\
\text { transcription } \\
\text { factor }\end{array}$ & [76], [77] and [78] \\
\hline \multirow[t]{3}{*}{ Fruit Shape } & fs8.1 (Q) & 8 & L. pimpinellifolium & $\mathrm{NIL} \mathrm{F}_{2}$ & $\begin{array}{l}\text { Imparts Blocky, } \\
\text { Elongated Shape }\end{array}$ & [79] and [80] \\
\hline & $\operatorname{Sun}(Q)$ & 7 & L. esculentum & $\begin{array}{l}\mathrm{NIL} \mathrm{F}_{2} \text { and } \\
\mathrm{F}_{3}\end{array}$ & $\begin{array}{l}\text { Imparts oval } \\
\text { Shape }\end{array}$ & [80] and [81] \\
\hline & ovate (Q) & 2 & L. pimpinellifolium & $\mathrm{NIL} \mathrm{F}_{2}$ & $\begin{array}{l}\text { Plant-Growth } \\
\text { Suppressor }\end{array}$ & {$[80]$} \\
\hline Fruit Weight & fw2.2 & 2 & L. pennellii & NIL $F_{2}$ & Controls Carpel Cell Number & [27] and [80] \\
\hline Growth Habit & PW9-2-5 & 9 & L. pennellii & $\mathrm{F}_{2}$ & Determinate Growth & {$[82]$} \\
\hline \multirow[t]{2}{*}{ Jointless } & $J$ & 11 & L. esculentum & $\mathrm{F}_{2}, \mathrm{NIL} \mathrm{F}_{2}$ & $\begin{array}{l}\text { Suppress Formation of } \\
\text { Pedicel Abscission Zone }\end{array}$ & [24] \\
\hline & $j-2$ & 12 & L. cheesmanii & $\mathrm{F}_{2}$ & $\begin{array}{l}\text { Suppress Formation of } \\
\text { Pedicel Abscission Zone }\end{array}$ & [83] and [84] \\
\hline Self Pruning (Sp) & $S p$ & 6 & L. esculentum & $\mathrm{NIL} \mathrm{F}_{2}$ & $\begin{array}{l}\text { Regulate Cycle of Vegetative } \\
\text { and Reproductive Growth }\end{array}$ & {$[22]$} \\
\hline Self Pruning (Sp) & $\begin{array}{l}\text { sp21, sp3D, } \\
\text { sp5G, sp6A,sp9D }\end{array}$ & $2,3,5,6,9$ & L. pennellii & $\mathrm{NIL} \mathrm{F}_{2}$ & Not determined & {$[23]$} \\
\hline Trichomes & Ptl1 & 10 & Capsicum annuum & $\mathrm{F}_{2}$ & Trichome Formation & [32] \\
\hline Growth Habit & Bnsdt1 & 10 & Brassica napus & $\mathrm{BC}_{1}$ & Determinate & [85] \\
\hline Tender Spines & ts & 1 & Cucumis sativus & $\mathrm{F}_{2}$ & Receptor like kinase & [49] \\
\hline White Immature Fruit Color & W & 3 & Cucumis sativus & $F_{2}$ & $\begin{array}{l}\text { Chloroplast Development and } \\
\text { Chlorophyll Biosynthesis }\end{array}$ & {$[50]$} \\
\hline Spine Color & $B$ & 4 & Cucumis sativus & $\mathrm{F} 2$ & $\begin{array}{l}\text { R2R3-MYB Transcription } \\
\text { factor }\end{array}$ & [86] \\
\hline \multirow[t]{2}{*}{ Flesh Color } & $B$ & 04 & Citrullus lanatus & $\mathrm{F}_{2}$ & Carotenogenesis & {$[87]$} \\
\hline & Wf & 02 & Citrullus lanatus & $\mathrm{F}_{2}$ & carotenogenesis & [87] \\
\hline Yellow Seed Coat & Brsc1 & 09 & Brassica rapa & $\mathrm{BC}_{4}$ & Zinc Finger Protein & [88] \\
\hline Plant Tendrils & $t d-1$ & 06 & Cucumis sativus & $\mathrm{F}_{2}$ & Histone Acetyltransferase & [89] \\
\hline Plant Height & $B n D W F 1$ & 09 & Brassica napus & $\mathrm{BC}_{1}$ & Dwarf Trait & [88] \\
\hline Glossy Green Trait & BoGL1 & 08 & Brassica oleracea var. capitata & $\mathrm{F}_{2}$ & wax biosynthesis reduction & {$[90]$} \\
\hline Fruit Weight & fw11.3 & 11 & Solanum lycopersicum & $\mathrm{BC}_{1} \mathrm{~F}_{5}$ & Controls carpel cell number & [91] \\
\hline
\end{tabular}




\begin{tabular}{|c|c|c|c|c|c|c|}
\hline Virescent Leaf Gene & $v-1$ & 06 & Cucumis sativus & RIL & $\begin{array}{l}\text { Delayed chloroplast } \\
\text { Development }\end{array}$ & {$[92]$} \\
\hline Glossiness & Cgl1 & 08 & Brassica oleracea var. capitata & $\mathrm{F}_{2}$ & Wax Biosynthesis Gene & {$[90]$} \\
\hline Purple leaf colour & $\mathrm{BoPr}$ & 09 & Brassica oleracea var.acephala & $\mathrm{BC}_{1}$ and $\mathrm{F}_{2}$ & Dihydroflavonol Reductase & {$[90]$} \\
\hline \multicolumn{7}{|c|}{ Nutritional Traits } \\
\hline Brix (Soluble Solids) & Brix9-2-5,Lin5(Q) & 9 & L. pennellii & $\mathrm{NIL} \mathrm{F}_{2}$ & Apoplastic Invertase & {$[82]$} \\
\hline Iron Uptake & Chloronerva & 1 & L. pennellii & $\mathrm{NIL} \mathrm{F}_{2}$ & Nicotianamine Synthase & [93] \\
\hline B-Carotene & Or & & Cauliflower & $\mathrm{F}_{2}$ & Plastid-Associated Protein & {$[40]$} \\
\hline Anthocyanin accumulation & BnaA.PL1 & 03 & Brassica napus & $\mathrm{BC}_{1} \mathrm{P}_{2}$ & Anthocyanin Synthesis & {$[94]$} \\
\hline \multicolumn{7}{|c|}{ Male sterility } \\
\hline Genic male-sterility & $m s 1$ & 5 & Capsicum annuum & $\mathrm{F}_{2}$ & PHD-type Transcription factor & {$[95]$} \\
\hline \multirow[t]{3}{*}{ Genic male-sterile gene } & Bnms1 & 7 & Brassica napus & $\mathrm{NIL}$ & Male Sterility & {$[96]$} \\
\hline & BnMs2 & 16 & Brassica napus & $\mathrm{NIL}$ & Male Sterility & [97] \\
\hline & Bnms3 & 19 & Brassica napus & NIL & Male Sterility & [98] \\
\hline Genic Male Sterility & Ms-cd1 & 9 & Brassica oleracea & $\mathrm{BC}_{9}$ & $\begin{array}{l}\text { Ethylene-Evoked Salt } \\
\text { Tolerance }\end{array}$ & [43] \\
\hline $\begin{array}{l}\text { Cytoplasmic male sterility } \\
\text { (CMS) }\end{array}$ & orf687 & - & Kosena Radish & $\mathrm{F}_{2}$ & $\begin{array}{l}\text { Pentatricopeptide-Repeat } \\
\text { Protein }\end{array}$ & [99] \\
\hline Fertility Resteror Gene & $R f$ & 1 & Radish & $\mathrm{F}_{2}$ & $\begin{array}{l}\text { Pentatricopeptide-Repeat } \\
\text { Protein }\end{array}$ & {$[47]$} \\
\hline \multicolumn{7}{|c|}{ Self incompatibility } \\
\hline Self Incompatibility & $S$ & 1 & L. peruvianum & $\mathrm{N} / \mathrm{A}$ & RNase activity & [100] \\
\hline \multicolumn{7}{|c|}{ Temperature Sensitivity } \\
\hline Temperature Sensitive & sy-2 & 01 & Capsicum chinense & $\mathrm{F}_{2}$ & Low temperature Sensitivity & {$[50]$} \\
\hline \multicolumn{7}{|c|}{ Herbicides Resistance } \\
\hline Fenthion Resistance & Prf & 5 & L. pimpinellifolium & $\mathrm{NIL} \mathrm{F}_{2}$ & NBS-LRR, Resistance gene & [101] \\
\hline
\end{tabular}

\section{Conclusion}

The map-based cloning approach is a powerful strategy for identifying and isolating agronomically important genes controlling traits of economic importance. Studying multiple alleles of a gene can provide a nuanced understanding of gene function. While broadening the knowledge base of plant gene function, such research may not be of immediate importance to some breeders. Recovery of the causative mutation, however, provides a perfect genetic marker for introgression of alleles into different genetic backgrounds. The appropriate choice of methods will ultimately depend on details of the particular species, traits, and QTLs being studied. The map-based cloning approach also has some limitations for application to plant genetics viz., tedious, time consuming and requires large, preferably advanced, segregating populations. But the Presence of high throughput technology will probably lead to a greater interest for this approach in plant genetics

Application of review: The review describes the significance of cloning of agronomically important genes controlling traits of economic importance.

\section{Abbreviations:}

QTLs-quantitative trait loci, WHO-World Health Organization, RAPD-random amplified polymorphic DNA, SSR-simple sequence repeats, AFLPs-amplified fragment length polymorphisms, SNP- single nucleotide polymorphism etc.

Acknowledgement / Funding: Author thankful to ICAR-Indian Agricultural Research Institute, New Delhi, 110012.

\section{*Research Guide or Chairperson of research: Dr Manish Kumar University: ICAR- Indian Agricultural Research Institute, New Delhi \\ Research project name or number: None}

\section{Author contributions: All authors have equally contributed.}

Author statement: All authors reviewed and approved the final manuscript.

\section{Conflict of Interest: None declared}

Ethical approval: We hereby declare that this article does not contain any studies with human participants or animals performed by any of the authors.

\section{References}

[1] Anonymous (2003). Food and Agriculture Organization Database. http://www.fao.org.in

[2] Anonymous (2013) Vegtable statistics, Indian Institute of Vegetable Research 2013

[3] Anonymous (2017) Indian Horticulture Database. http://www.nhb.gov.in

[4] Jankowicz-Cieslak J. and Bradley J. (2015) Advances in Plant Breeding Strategies: Breeding, Biotechnology and Molecular Tools, 215-240.

[5] Peters J. L., Cnudde F. and Gerats T. (2003) Trends in Plant Science, 8, 484-491.

[6] Mayerhofer R., Wilde K., Mayerhofer M., Lydiate D., Bansal V. K. Good A. G. and Parkin I. A. (2005) Genetics, 171, 1977-1988.

[7] Lukowitz W., Gillmor C. S., Scheible W. (2000) Plant Physiology, 123 , 795-806.

[8] Botstein D., White R. L. Skolnick M. and Davis R. W. (1980) American Journal of Human Genetics, 32, 314-331.

[9] Williams J. G., Kubelik A. R., Livak K. J., Rafalski J. A. and Tingey S. V. (1990) Nucleic Acids Research, 18, 6531-6535.

[10] Hearne C. M., Ghosh S. and Todd, J. A. (1992) Trends in Genetics, 8 288-294.

[11] Zabeau M. and Vos P. (1993) European Patent Application Number 92402629.7. Publication Number 0534858 A1.

[12] Ganal M. W., Nevin D., Young N. D., Tanksley S. D. (1989) Molecular and General Genetics, 215, 395-400.

[13] Rommens J. M., lannuzzi M. C., Kerem B., Drumm M. L., Melmer G. Dean M., Rozmahel R., Cole J. L., Kennedy D. and Hidaka N. (1989) Science, 245, 1059-1065.

[14] Rosenberg M., Przybylska M., Straus D. (1994) Proceedings of the National Academy of Sciences of the United States of America, 91, 6113-6117.

[15] Rafalski A. (2002) Current Opinion in Plant Biology, 5, 94-100.

[16] Giraudat J., Hauge B. M., Valon C., Smalle J., Parcy F. and Goodman H. M. (1992) The Plant Cell, 4, 1251-1261.

[17] Arondel V., Lemieux B., Hwang I., Gibson S., Goodman H. M. and Somerville C. R. (1992) Science, 258, 1353-1355.

[18] Martin G. B., Brommonschenkel S. H., Chunwongse J., Frary A. Ganal M. W., Spivey R., Wu T., Earle E. D. and Tanksley S. D. (1993) Science, 262, 1432-1436.

[19] Kawchuk L. M., Hachey J. and Lynch D. R. (1998) Genome, 41, 91-95.

[20] Oldroyd G. E. and Staskawicz B. J. (1998) Proceedings of the National Academy of Sciences, 95, 10300-10305. 
[21] Brommonschenkel S. H. and Tanksley S. D. (1997) Molecular and General Genetics, 256, 121-126.

[22] Pnueli L., Carmel-Goren L., Hareven D., Gutfinger T., Alvarez J., Ganal M., Zamir D. and Lifschitz E. (1998) Development, 125, 19791989.

[23] Carmel-Goren L., Liu Y. S., Lifschitz E. and Zamir D. (2003) Plant Molecular Biology, 52, 1215-1222.

[24] Mao L., Begum D., Chuang H. W., Budiman M. A., Szymkowiak E. J., Irish E. E. and Wing R. A. (2000) Nature, 406, 910-913.

[25] Remington D. L., Ungerer M. C. and Purugganan M. D. (2001). Genetics Research, 78, 213-218.

[26] Foolad M. R. (2007) International Journal of Plant Genomics, 2007, 152.

[27] Frary A., Nesbitt T. C., Grandillo S., Knaap E., Cong B., Liu J., Meller J., Elber R., Alpert K. B. and Tanksley S. D. (2000) Science, 289, 85-8.

[28] Cong B., Liu J. and Tanksley S. D. (2002) Proceedings of the National Academy of Sciences, 99, 13606-13611.

[29] Liu J., Cong B. and Tanksley S. D. (2003) Plant Physiology, 132, 292299.

[30] Tai T. H., Dahlbeck D., Clark E. T., Gajiwala P., Pasion R., Whalen M. C., Stall R.E. and Staskawicz B. J. (1999) Proceedings of the National Academy of Sciences, 96, 14153-14158.

[31] Jo Y. D., Ha Y., Lee J. H., Park M., Bergsma A. C., Choi H. I., Goritschnig S., Kloosterman B., van Dijk P.J., Choi D. and Kang B. C. (2016) Theoretical and Applied Genetics, 129, 2003-2017.

[32] Kim H. J., Han J. H., Kwon J. K., Park M., Kim B. D. and Choi D. (2010) Theoretical and Applied Genetics, 120, 1099-1106.

[33] Rao G. U. and Paran I. (2003) Plant Molecular Biology, 51, 135-141.

[34] Lefebvre V., Kuntz, M., Camara, B. and Palloix, A. (1998) Plant Mol Biol., 36(5), 785-789.

[35] Thorup T. A., Tanyolac B., Livingstone K. D., Popovsky S., Paran I. and Jahn M. (2000) Proceedings of the National Academy of Sciences, 97, 11192-11197.

[36] Huh J. H., Kang B. C., Nahm S. H., Kim S., Ha K. S., Lee M. H. and Kim B. D. (2001) Theoretical and Applied Genetics, 102, 524-530.

[37] Stewart C., Kang B.C., Liu K., Mazourek M., Moore S.L., Yoo E.Y., Kim B.D., Paran I. and Jahn M.M. (2005) The Plant Journal, 42, 675688.

[38] Ruffel S., Dussault M. H., Palloix A., Moury B., Bendahmane A., Robaglia C. and Caranta C. (2002) The Plant Journal, 32, 1067-1075.

[39] Kang B. C., Yeam I., Frantz J. D., Murphy J. F. and Jahn M. M. (2005) The Plant Journal, 42, 392-405.

[40] Lu S., Van Eck J., Zhou X., Lopez A. B., O'Halloran D. M., Cosman K. M., Conlin B. J., Paolillo D. J., Garvin D. F., Vrebalov J. and Kochian L. V. (2006) The Plant Cell, 18, 3594-3605.

[41] Shimizu M., Fujimoto R., Ying H., Pu Z. J., Ebe Y., Kawanabe T., Saeki N., Taylor J. M., Kaji M., Dennis E. S. and Okazaki K. (2014) Plant Molecular Biology, 85, 247-257.

[42] Shimizu M., Pu Z. J., Kawanabe T., Kitashiba H., Matsumoto S., Ebe Y., Sano M., Funaki T., Fukai E., Fujimoto R. and Okazaki K. (2015) Theoretical and Applied Genetics, 128, 119-130.

[43] Liang J., Ma Y., Wu J., Cheng F., Liu B. and Wang X. (2017) Theoretical and Applied Genetics, 130, 71-79.

[44] Imai R., Koizuka N., Fujimoto H., Hayakawa T., Sakai T. and Imamura J. (2003) Molecular Genetics and Genomics, 269, 388-394.

[45] Brown G. G., Formanova N., Jin H., Wargachuk R., Dendy C., Patil P., Laforest M., Zhang J., Cheung W. Y. and Landry B. S. (2003) The Plant Journal, 35, 262-272.

[46] Desloire S., Gherbi H., Laloui W., Marhadour S., Clouet V., Cattolico L., Falentin C., Giancola S., Renard M., Budar F. and Small I. (2003) EMBO Reports, 4, 588-594.

[47] Giancola S., Marhadour S., Desloire S., Clouet V., FalentinGuyomarch H., Laloui W., Falentin C., Pelletier G., Renard M.,
Bendahmane A. and Delourme R. (2003) Theoretical and Applied Genetics, 107, 1442-1451.

[48] Cai D., Kleine M., Kifle S., Harloff H. J., Sandal N. N., Marcker K. A., Klein-Lankhorst R. M., Salentijn E. M., Lange W., Stiekema W. J. and Wyss U. (1997) Science, 275, 832-834.

[49] Guo C., Yang X., Wang Y., Nie J., Yang Y., Sun J., Du H., Zhu W., Pan J., Chen Y., Lv D., He H., Lian H., Pan J. and Cai R. (2018) Theoretical and Applied Genetics, 131, 1-12.

[50] Liu H., Jiao J., Liang X., Liu J., Meng H., Chen S., Li Y. and Cheng Z. (2016) Theoretical and Applied Genetics, 129, 1247-1256.

[51] Joobeur T., King J. J., Nolin S. J., Thomas C. E. and Dean R. A. (2004) The Plant Journal, 39, 283-297.

[52] Pauquet J., Burget E., Hagen L., Chovelon V., Le Menn A., Valot N., Desloire S., Caboche M., Rousselle P., Pitrat M. and Bendahmane A. (2004) Proceedings of Cucurbitaceae, 325-329.

[53] Morales M., Orjeda G., Nieto C., van Leeuwen H., Monfort A. Charpentier M., Caboche M., Arus P., Puigdomènech P., Aranda M. A., Dogimont C., Bendahmane A. and Garcia-Mas J. (2005) Theoretical and Applied Genetics, 111, 914-922.

[54] Garcia-Mas J., Morales M., van Leeuwen H., Monforte A.J. and Puigdomenech P. (2004) In: Progress in Cucurbit Genetics and Breeding Research, 209-212.

[55] Ori N., Eshed Y., Paran I., Presting G., Aviv D., Tanksley S. D. Zamir D., Fluhr R. (1997) The Plant Cell, 9, 521-532.

[56] Simons G., Groenendijk J., Wijbrandi J., Reijans M., Groenen J., Diergaarde P., Van der Lee T., Bleeker M., Onstenk J., de Both M. and Haring M. (1998) The Plant Cell, 10, 1055-1068.

[57] Jones N., Ougham H., Thomas H. and Pasakinskiene I. (2009) New Phytologist, 183, 935-966.

[58] Rossi M., Goggin F. L., Milligan S. B., Kaloshian I., Ullman D. E. and Williamson V. M. (1998) Proceedings of the National Academy of Sciences, 95, 9750-9754.

[59] Vos P., Simons G., Jesse T., Wijbrandi J., Heinen L., Hogers R., Frijters A., Groenendijk J., Diergaarde P., Reijans M. and FierensOnstenk J. (1998) Nature Biotechnology, 16, 1365-1369.

[60] Milligan S. B., Bodeau J., Yaghoobi J., Kaloshian I., Zabel P. and Williamson V. M. (1998) The Plant Cell, 10, 1307-1319.

[61] Bogdanove A. J. (2002) Molecular Plant Pathology, 3, 283-288.

[62] Gu Y. Q. and Martin G. B. (1998) In: Philosophical Transactions of the Royal Society, Biological Sciences, 353, 1455-1461.

[63] Dixon M. S., Jones D. A., Keddie J. S., Thomas C. M., Harrison K. and Jones J. D. (1996) Cell, 84, 451-459.

[64] Jo K. R., Arens M., Kim T. Y., Jongsma M. A., Visser R. G., Jacobsen E. and Vossen J. H. (2011) Theoretical and Applied Genetics, 123, $1331-1340$.

[65] Huang Z., Peng G., Liu X., Deora A., Falk K. C., Gossen B. D., McDonald M. R. and Yu F. (2017) Frontiers in Plant Science, 8, 1448.

[66] Venkatesh J., An J., Kang W. H., Jahn M. and Kang B. C. (2018) Phytopathology, 108, 142-148.

[67] Jo J., Venkatesh J., Han K., Lee H. Y., Choi G. J., Lee H. J., Choi D. and Kang B. C. (2017) Frontiers in Plant Science, 8, 1-11.

[68] Liu L., Venkatesh J., Jo Y. D., Koeda S., Hosokawa M., Kang J. H., Goritschnig S. and Kang B. C. (2016) Theoretical and Applied Genetics, 129, 1541-1556.

[69] Hurtado-Gonzales O. P., Valentini G., Gilio T. A., Martins A. M., Song Q. and Pastor-Corrales M. A. (2017) G3: Genes, Genomes, Genetics, 7, 557-569.

[70] Keller B., Manzanares C., Jara C., Lobaton J. D., Studer B. and Raatz B. (2015) Theoretical and Applied Genetics, 128, 813-826.

[71] Chen F., Fu B., Pan Y., Zhang C., Wen H., Weng Y., Chen P. and Li Y. (2017) Theoretical and Applied Genetics, 130, 1549-1558.

[72] Ronen G., Cohen M., Zamir D. and J. Hirschberg J. (1999) The Plant Journal, 17, 341-351. 
[73] Ronen G., Carmel-Goren L., Zamir D. and Hirschberg J. (2000) Proceedings of the National Academy of Sciences of the United States of America, 97, 11102-11107.

[74] Isaacson T., Ronen G., Zamir D. and Hirschberg J. (2002) The Plant Cell, 14, 333-342.

[75] Yen H.C., Lee S., Tanksley S. D., Lanahan M. B., Klee H. J. and Giovannoni J. J. (1995) Plant Physiology, 107, 1343-1353.

[76] Moore S., Vrebalov J., Payton P. and Giovannoni J. (2002) Journal of Experimental Botany, 53, 2023-2030.

[77] Giovannoni J. J., Noensie E.N., Ruezinsky D. M., Lu X., Tracy S. L., Ganal M. W., Martin G. B., Pillen K., Albert K. and Tankslev S. D. (1995) Molecular and General Genetics, 248, 195-206.

[78] Vrebalov J., Ruezinsky D., Padmanabhan V., White R., Medrano D., Drake R., Schuch W. and Giovannoni J. (2002) Science, 296, 343346.

[79] Ku H. M., Grandillo S. and Tanksley S. D. (2000) Theoretical and Applied Genetics, 101, 873-878.

[80] Tanksley S. D. (2004) The Plant Cell, 16, S181-S189.

[81] Van der Knaap E., Sanyal A., Jackson S.A. and Tanksley S. D. (2004) Genetics, 168, 2127-2140.

[82] Fridman E., Liu Y., Carmel-Goren L., Gur A., Shoresh M., Pleban T., Eshed Y. and Zamir D. (2002) Molecular Genetics and Genomics, 266, 821-826.

[83] Zhang H. B., Budiman M. A. and Wing R. A. (2000) Theoretical and Applied Genetics, 100, 1183-1189.

[84] Budiman M. A., Chang S. B., Lee S., Yang T. J., Zhang H. B., De Jong H. and Wing R. A. (2004) Theoretical and Applied Genetics, 108, 190196.

[85] Li K., Yao Y., Xiao L., Zhao Z., Guo S., Fu Z. and Du D. (2018) Theoretical and Applied Genetics, 131, 193-208.

[86] Li Y., Wen, C. and Weng Y. (2013) Theoretical and Applied Genetics, 126, 2187-2196.

[87] Jie Z., Guoyi G., Shaogui G., Yi R., Haiying Z. And Yong X. (2014) Proceedings of Cucurbitaceae, pp.111.

[88] Wang Y., Xiao L., Guo S., An F. and Du D. (2016) PloS one, 11, 0166464.

[89] Chen F., Fu B., Pan Y., Zhang C., Wen H., Weng Y., Chen P. and Li Y. (2017) Theoretical and Applied Genetics, 130, 1549-1558.

[90] Liu Z., Fang Z., Zhuang M., Zhang Y., Lv H., Liu Y., Li Z., Sun P., Tang J., Liu D. and Zhang Z. (2017) Frontiers in Plant Science, 8, 239.

[91] Huang Z. and Van der Knaap E. (2011) Theoretical and Applied Genetics, 123, 465-474.

[92] Miao H., Zhang S., Wang M., Wang Y., Weng Y. and Gu X. (2016) International journal of molecular sciences, 17, 1602.

[93] Ling H.Q., Koch G., Bäumlein H. and Ganal M. W. (1999) Proceedings of the National Academy of Sciences of the United States of America, 96, 7098-7103.

[94] Li, H., Zhu L., Yuan G., Heng S., Yi B., Ma C., Shen J., Tu J., Fu T. and Wen J. (2016) Molecular Genetics and Genomics, 291, 15231534.

[95] Jeong K., Choi D. and Lee J. (2018) Theoretical and Applied Genetics 131, 183-191.

[96] Yi B., Chen Y., Lei S., Tu J. and Fu T. (2006) Theoretical and Applied Genetics, 113, 643-650.

[97] Lei S., Yao X., Yi B., Chen W., Ma C., Tu J. and Fu T. (2007) Theoretical and Applied Genetics, 115, 643-651.

[98] Huang Z., Chen Y., Yi B., Xiao L., Ma C., Tu J. and Fu T. (2007) Theoretical and Applied Genetics, 115, 113-118.

[99] Koizuka N., Imai R., Fujimoto H., Hayakawa T., Kimura Y. Kohno-Murase J., Sakai T., Kawasaki S. and Imamura J. (2003) The Plant Journal, 34, 407-415.

[100] Rivers B. A., Bernatzky R., Robinson S. J. and Jahnen-Dechent W. (1993) Molecular Genetics and Genomics, 238, 419-427.
[101] Salmeron J. M., Oldroyd G. E., Rommens C. M., Scofield S. R., Kim H. S., Lavelle D. T., Dahlbeck D. and Staskawicz B. J. (1996) Cell, 86 , 123-133. 